\title{
Colocalization of NGF Binding Sites, trk mRNA, and Low-affinity NGF Receptor mRNA in Primary Sensory Neurons: Responses to Injury and Infusion of NGF
}

\author{
V. M. K. Verge, , ${ }^{1,2}$ J.-P. Merlio, ${ }^{3}$ J. Grondin, ${ }^{1}$ P. Ernfors, ${ }^{3}$ H. Persson, ${ }^{3}$ R. J. Riopelle, ${ }^{4}$ T. Hökfelt, ${ }^{2}$ and P. M. \\ Richardson' \\ 'Division of Neurosurgery, McGill University and Montreal General Hospital, Montreal, Canada H3G 1A4, ${ }^{2}$ Department of \\ Histology and Neurobiology and ${ }^{3}$ Department of Medical Chemistry, Laboratory of Molecular Neurobiology, Karolinska \\ Institute, S 10401 Stockholm, Sweden, and 4Division of Neurology, Queen's University, Kingston, Canada K7L 2V7
}

The distributions of mRNAs for the protooncogene trk and the low-affinity NGF receptor (LNGFR) were studied by hybridization with oligonucleotide probes on sections of adult rat primary sensory and sympathetic ganglia. For comparison with high-affinity binding sites, adjacent sections were processed for NGF receptor radioautography. Among neurons in lumbar dorsal root ganglia and trigeminal ganglia, trk mRNA and NGF-binding sites were closely colocalized; this finding together with previous direct evidence in other cell types is taken to indicate that trk protein is an essential component of the high-affinity NGF receptor in adult sensory neurons. In lumbar dorsal root ganglia and trigeminal ganglia, abundant LNGFR mRNA was found in all neurons with strong 120|-NGF labeling and on additional neurons lacking highaffinity NGF-binding sites. The presence of abundant LNGFR in neurons with high-affinity receptors could be the cause and/or consequence of their ability to respond to NGF. Neurons with abundant LNGFR mRNA but few high-affinity NGFbinding sites may have receptors for other members of the neurotrophin family. In nodose ganglia, neurons with high concentrations of LNGFR mRNA greatly outnumbered the small percentage with abundant trk mRNA. Following intrathecal infusion of NGF to otherwise normal dorsal root ganglia, the concentrations of LNGFR mRNA but not those of trk mRNA and NGF-binding sites were increased in NGFresponsive neurons. The usual single normal pattern of frequency histograms of LNGFR labeling indices became bimodal in response to NGF. Concentrations of NGF-binding sites, LNGFR mRNA, and trk mRNA were all decreased by peripheral nerve transection and restored by exogenous NGF, the restoration being complete for LNGFR mRNA and partial for trk mRNA and NGF-binding sites. The data indicate that NGF can regulate both LNGFR and trk mRNAs but do not clarify the possible contribution of the LNGFR protein to highaffinity binding sites.

\footnotetext{
Received Mar. 23, 1992; revised May 20, 1992; accepted May 26, 1992.

This work was supported by the Canadian and Swedish Medical Research Councils and the Parkinson Foundation of Canada.

Correspondence should be addressed to Dr. Peter Richardson, Division of Neurosurgery, Montreal General Hospital, 1650 Cedar Avenue, Montreal, Canada H3G 1 A4.

Copyright (c) 1992 Society for Neuroscience $0270-6474 / 92 / 124011-12 \$ 05.00 / 0$
}

The ability to bind NGF at high affinity and internalize NGF appears to be a stable property of a subpopulation of primary sensory neurons in the normal adult rat (Richardson and Riopelle, 1984; Verge et al., 1989a). The NGF-responsive population of lumbar dorsal root ganglion (DRG) neurons includes those with calcitonin gene-related peptide immunoreactivity and substance $\mathrm{P}$ immunoreactivity but not those with somatostatin immunoreactivity (Verge et al., 1989b). Little is known about genetic and developmental influences that determine which $40 \%$ of sensory neurons in the adult animal come to have functional high-affinity NGF receptors. However, the number of high-affinity NGF receptors on this fixed population of mature neurons has been shown to be reduced by axotomy and partially restored by infusion of exogenous NGF (Verge et al., 1989a). Prolonged administration of NGF can also increase the number of high-affinity NGF receptors on pheochromocytoma cells (Bernd and Greene, 1984).

Two molecules have been implicated in the high-affinity binding (Sutter et al., 1979), internalization, and signal transduction of NGF-the $140 \mathrm{kDa}$ protein product of the protooncogene trk (Martin-Zanca et al., 1989) and the $75 \mathrm{kDa}$ low-affinity NGF receptor (LNGFR) (Johnson et al., 1986; Radeke et al., 1987; Large et al., 1989). The trk protein binds NGF (Kaplan et al., $1991 \mathrm{~b}$ ), is quickly phosphorylated upon exposure to NGF (Kaplan et al., 1991a), and can mediate mitotic responses to NGF upon transfection into a quiescent fibroblast cell line lacking LNGFR (Cordon-Cardo et al., 1991). trk protein is generally agreed to be a necessary constituent of the functional NGF receptor (Loeb et al., 1991) in pheochromocytoma cells either as the entire receptor (Klein et al., 1991a; Weskamp and Reichardt, 1991) or as a major component of a receptor complex (Hempstead et al., 1991). LNGFR by itself mediates no biological action of NGF and is not necessary for several biological responses (Cordon-Cardo et al., 1991; Ibáñez et al., 1992). However, LNGFR may be required for high-affinity binding of NGF with equilibrium dissociation constant in the order of $10^{-11} \mathrm{M}$ (Hempstead et al., 1991) and is present in all neurons known to respond physiologically to NGF by survival and neurite extension. In short, trk protein is an important component of the functional NGF receptor and the contribution of LNGFR is still somewhat ambiguous.

At least some neurons in most sensory ganglia respond to NGF. The same statement is true for BDNF (brain-derived 
neurotrophic factor), NT-3 (neurotrophin-3), or NT-5, although the proportions responding to the four neurotrophins vary among ganglia (Davies et al., 1986; Ernfors et al., 1990; Berkemeier et al., 1991). LNGFR binds BDNF and NT-3 as well as NGF with low affinity and has been proposed to be a common component of diverse high-affinity receptors for NGF-like molecules (Ernfors et al., 1990; Rodriguez-Tébar et al., 1990). trk protein is not a receptor for BDNF but shows some responses to $\mathrm{N}^{\prime} \mathrm{l}-3$ and NT-5 (Berkemeier et al., 1991; Cordon-Cardo et al., 1991). Other members of the trk family, trk B and trk C, appcar to be responsible for signal transduction of BDNF and NT-3 (Klein et al., 1991b; Lamballe et al., 1991; Soppet et al., 1991; Squinto et al., 1991).

In an attempt to clarify the roles of LNGFR and trk in highaffinity NGF binding, the distributions of NGF-binding sites, LNGFR mRNA, and trk mRNA were correlated for rat primary sensory neurons in several ganglia. Also, the effects of sciatic nerve transection and intrathecal infusion of NGF were analyzed in lumbar DRG neurons and correlated with earlier observations with NGF receptor radioautography (Verge et al., 1989a).

\section{Materials and Methods}

Surgery and tissue preparation. Experiments were performed on Sprague-Dawley rats of either sex weighing approximately $200 \mathrm{gm}$ and anesthetized for surgery with pentobarbital, $50 \mathrm{mg} / \mathrm{kg}$ intraperitoneally. In 28 rats, the right sciatic nerve was transectcd at its origin from the $L 4$ and L5 spinal nerves and one-half of these rats were infused immediately or subsequently with $\beta$-NGF, prepared from mouse submandibular glands by cation-exchange chromatography (Longo et al., 1989). For administration of NGF, an osmotic pump (Alza, 2001) was inserted in the dorsal lumbar subcutaneous space and attached to silicon tubing $(0.3$ $\mathrm{mm}$ o.d.) inserted $3 \mathrm{~cm}$ into the subarachnoid space from the lumbosacral junction. NGF was delivered at $125 \mathrm{ng} / \mathrm{hr}$ in a solution of phosphate-buffered saline containing bovine serum albumin $(1 \mathrm{mg} / \mathrm{ml})$, streptomycin $(100 \mathrm{U} / \mathrm{ml})$, and penicillin $(100 \mathrm{U} / \mathrm{ml})$. Control rats were infused with buffered solution alone. Three to four weeks after sciatic nerve transection and 1 week after insertion of osmotic pumps, rats were deeply anesthetized and perfused per aorta with phosphate-buffered saline. The right and left L5 DRG (fifth lumbar dorsal root ganglia) were frozen at $-60^{\circ} \mathrm{C}$ in one mold containing Tissue-Tck (Milcs Laboratories). Before sectioning, blocks containing DRG from NGF-infused and uninfused rats were fused by embedding medium so that four DRG could be sectioned on the same chuck and mounted on the same slide. In addition to lumbar DRG, nodose, trigeminal, and superior cervical ganglia were removed from normal rats and frozen in the same molds. Sections from DRG, nodose, trigeminal, and sympathetic ganglia were cut on a cryostat set at $5 \mu \mathrm{m}$ and mounted on gelatin-coated slides or commercially coated slides (Probe-on, Fisher). Sections were stored at $-80^{\circ} \mathrm{C}$ until use.

NGF receptor radioautography. As described in previous publications (Richardson et al., 1989; Verge et al., 1989a), sections were incubated for $90 \mathrm{~min}$ at room temperature in a solution of $30-80 \mathrm{pM}{ }^{125}$ I-NGF in phosphate-buffered $0.1 \mathrm{M}$ saline containing magnesium chloride $(0.5$ $\mathrm{mM})$, cytochrome C (1 gm/liter), phenylmethylsulfonyl fluoride $(0.5$ $\mathrm{mM}$ ), and leupeptin ( $4 \mathrm{mg} /$ liter). Slides were rinsed in several changes of cold buffer over $3 \mathrm{~min}$, fixed in buffered $2 \%$ formaldehyde $/ 2 \%$ glutaraldehyde, defatted in alcohols and xylene, rehydrated, and dried. They were then dipped in Kodak NTB-2 emulsion diluted with equal volume of distilled water, exposed in the dark for 4-10 d, developed, stained with toluidine blue, and mounted with a coverslip.

In situ hybridization. In situ hybridization with oligonucleotide probes for LNGFR and trk was performed on sections adjacent to those used for NGF receptor radioautography.

A 50-mer DNA oligonucleotide, 5'-ACAAGGCCCACGACCACAGCAGCCAAGATGGAGCAATAGACAGGAATGAG-3', was prepared complementary to the CDNA encoding the highly conserved transmembrane segment of LNGFR (Ernfors et al., 1989) and labeled with ${ }^{35} \mathrm{~S}-\mathrm{dATP}$ by the terminal transferase method (Ausubel et al., 1987). Cryostat sections taken from the freezer were fixed for $30 \mathrm{~min}$ in $4 \%$ paraformaldehyde, rinsed in buffered saline, dehydrated in alcohols, deproleinized with chloroform for $3 \mathrm{~min}$, rinsed in alcohol, and dried in air. The sections were hybridized overnight at $42^{\circ} \mathrm{C}$ in $1,000,000$ $\mathrm{cpm}$ of probe in $100 \mu \mathrm{l}$ of a solution containing formamide $(50 \%), 4 \times$ saline-sodium citrate (SSC), dextran sulfate (100 gm/liter), sarcosyl ( $1 \%)$, salmon sperm DNA (250 mg/liter), yeast tRNA (500 mg/liter), dithiothreitol (DTT; $50 \mathrm{mM}$ ), and phosphate buffer $(0.02 \mathrm{M}, \mathrm{pH} 7.0)$. They were then washed four times with $1 \times \mathrm{SSC}$ for $15 \mathrm{~min}$ at $55^{\circ} \mathrm{C}$, rinsed very briefly in distilled water, dried, dipped in Kodak NTB2 emulsion diluted $1: 1$ with distilled water, exposed in the dark at $4^{\circ} \mathrm{C}$ for 7-14 d, developed, stained with toluidine blue, and mounted with a coverslip.

For trk hybridization, an antisense oligonucleotide to rat trk mRNA 5'-AAGGTTGAACTCAAAAGGGTTGTCCATGAAGGCAGCCATGATGGAGGC-3' (J.-P. Merlio, P. Ernfors, and H. Persson, unpublished observations; Meakin et al., 1992) was labeled at the 3 ' end with ${ }^{3} \mathrm{~S}$ dATP. The rat trk oligonucleotide is the counterpart of base pairs 11981245 in the human trk sequence (Martin-Zanca et al., 1989) lying between the second immunoglobulin domain (Schneider and Schweiger, 1991) and the transmembrane domain. In this region of the rat trk protein, 9 of 17 amino acids are homologous with those in trk B and 4 of 17 are homologous with those in trk C. As previously described (Dagerlind et al., 1990), sections were removed from the freezer, dried for $20-40 \mathrm{~min}$ at room temperature, and hybridized overnight at $42^{\circ} \mathrm{C}$ with $10^{7} \mathrm{cpm}$ of ${ }^{35} \mathrm{~S}$-labeled probe in $1 \mathrm{ml}$ of hybridization solution containing formamide (50\%), $4 \times \mathrm{SSC}$, dextran sulfate $(100 \mathrm{gm} / \mathrm{liter})$, sarcosyl (1\%), $0.02 \mathrm{M}$ phosphate buffer, salmon sperm DNA (500 gm/ liter), and DTT (200 mM). Following hybridization, slides were washed four times with $1 \times \mathrm{SSC}$ for $15 \mathrm{~min}$ at $55^{\circ} \mathrm{C}$, brought to room temperature in the final rinse, rinsed briefly in distilled water, and quickly dehydrated in ascending concentrations of alcohol. Tissue sections were dipped in NTB2 emulsion diluted 1:1 in distilled water, exposed in the dark for 6-10 d, developed, stained with toluidine blue, and mounted with coverslips.

Quantification. Radioautographic labeling was quantified on sections processed for NGF receptor radioautography or in situ hybridization with trk or LNGFR probes. Under oil immersion light microscopy with an interactive image analysis system (Richardson et al., 1989), the percentages of cytoplasmic area covered by silver grains were measured for individual numbered neurons in both preparations of each ganglion. For each image, the density threshold was adjusted interactively so that the area per grain was constant for all neurons. Correction for grain overlap was made to obtain a parameter linearly related to density of silver grains (Richardson et al., 1989). The term labeling index refers to the ratio of grain density over neuronal cytoplasm to grain density over areas of the ganglia without neuronal cell bodies. Software for the image analysis system was generously provided by W. G. Tatton (University of Toronto) and supplemented with published programs for data analysis (Press et al., 1988). In colocalization studies of lumbar DRG, nodose ganglia, or trigeminal ganglia, montages of photomicrographs (magnification, $400 \times$ ) were prepared from pairs of adjacent sections, one processed for receptor radioautography and the other for hybridization with trk or LNGFR probes. Individual neurons with visible nucleolus in one of the two sections were identified, numbered, and quantified in each of the two sections. To avoid slide-to-slide variability, comparisons to determine the effect of nerve transection and/or NGF infusion were made only on sections mounted on the same slide.

\section{Results}

\section{Normal DRG}

As previously reported, high-affinity binding sites were heterogeneously distributed among neurons in normal L5 DRG (Fig. 1). Frequency histograms of labeling densities in NGF receptor radioautographs have been interpreted to indicate the presence of two populations of neurons, approximately $40 \%$ with and $60 \%$ without high-affinity receptors (Verge et al., 1989a).

In situ hybridization with the LNGFR probe yielded labeling that varied considerably among neurons. The distributions of the logarithms of LNGFR labeling indices in normal DRG seemed consistently to fit single normal distributions (Fig. 2A) with no suggestion of two populations. In colocalization studies of two normal L5 DRG (Fig. 2C,E), neurons with ${ }^{125} \mathrm{I}-\mathrm{NGF}$ binding labeling indices of $>3$ had LNGFR hybridization la- 

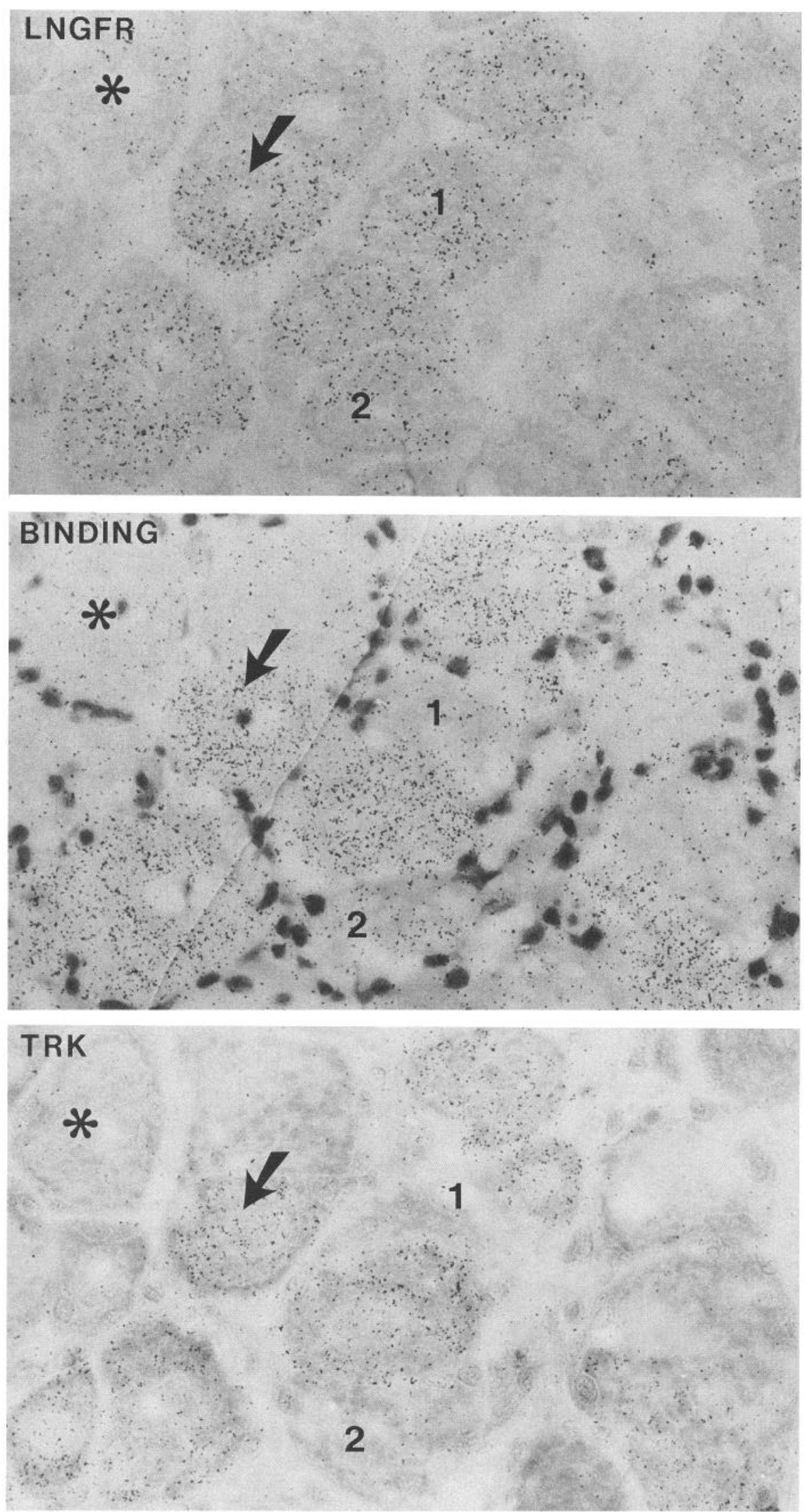

Figure 1. Photomicrographs showing adjacent cryostat sections, $5 \mu \mathrm{m}$ thick, of an L5 DRG processed for LNGFR hybridization (top), NGF receptor radioautography (middle), and trk hybridization (bottom). The neurons are heterogeneously labeled in all three preparations. Note the close correlation between strong expression of trk and the presence of high-affinity NGFbinding sites. All neurons with abundant trk mRNA also have abundant LNGFR mRNA and many ${ }^{125}$ I-NGF binding sites (arrows). All neurons with little or no LNGFR mRNA (asterisks) and a few neurons with abundant LNGFR mRNA (1 and 2) have undetectable concentrations of trk mRNA and high-affinity NGF-binding sites. Magnification, $610 \times$. 


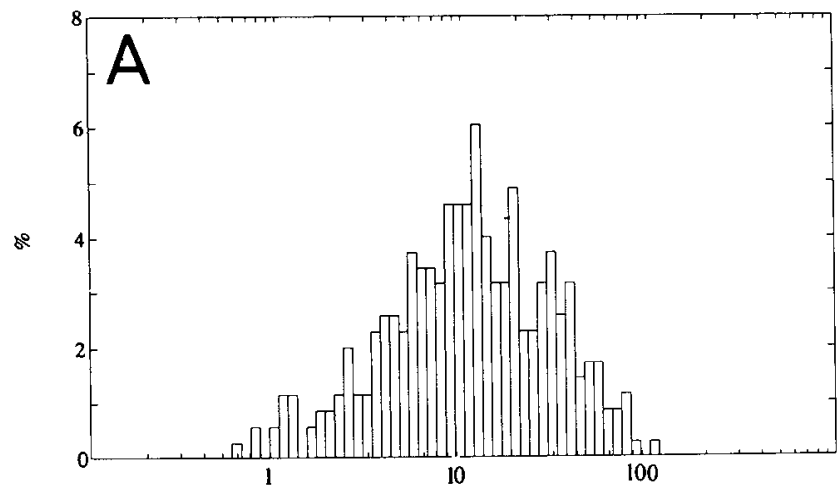

LNGFR IN SITU
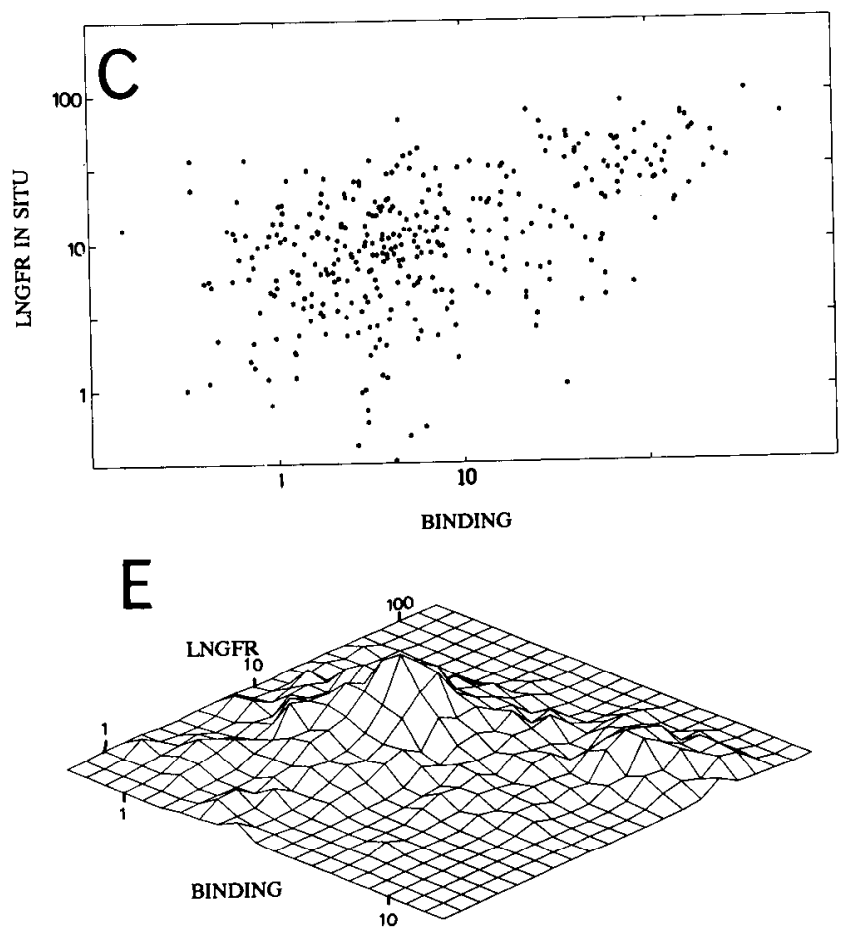
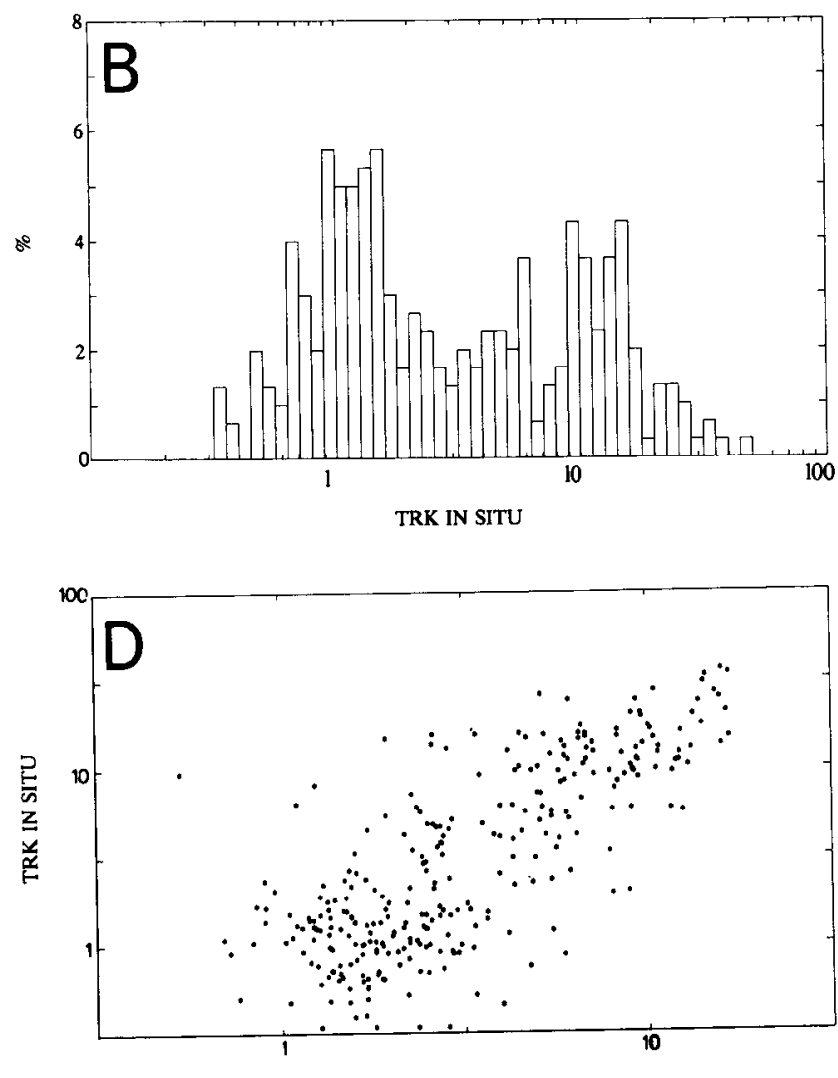

BINDING

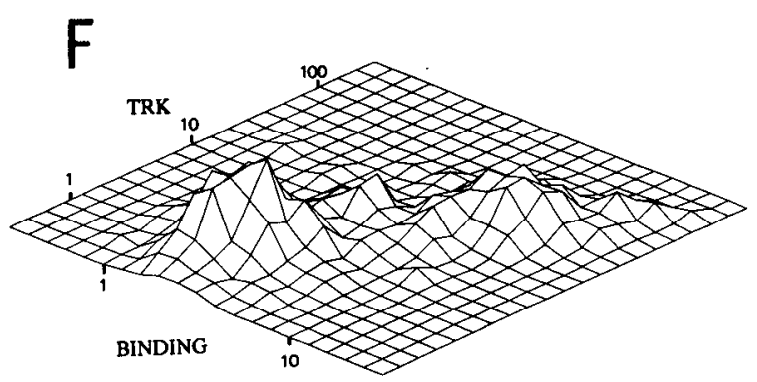

Figure 2. Frequency histograms of labeling indices $(A, B)$, scatter plots $(C, D)$, and three-dimensional histograms $(E, F$, with neuronal frequency as the z-axis) to quantify labeling of identified neurons in adjacent sections of L5 DRG processed for NGF receptor radioautography and either LNGFR hybridization $(A, C, E)$ or trk hybridization $(B, D, F)$. The frequency histogram of LNGFR labeling indices is unimodal $(A)$. Strongly NGF-positive neurons invariably are strongly LNGFR positive, but some neurons have abundant LNGFR mRNA and few NGF binding sites $(C$, $E)$. The frequency histogram of trk labeling is bimodal $(B)$. Labeling indices with trk hybridization and receptor radioautography are highly correlated, and two populations can be discerned with or without abundant trk mRNA and high-affinity NGF receptors $(D, F)$.

beling indices virtually always $>3$ and usually $>10$. The converse was not true as there were many neurons with LNGFR labeling indices of $>10$ but near background labeling in NGF receptor radioautography.

With trk hybridization, labeling of L5 DRG neurons was again heterogeneous, ranging from below background to $>100 \times$ background. Frequency histograms of the logarithms of trk labeling indices prepared for more than 200 neurons in each of three L5 DRG showed bimodal distributions (Fig. $2 B$ ). In colocalization analysis of one DRG (Fig. $2 D, F$ ), most neurons were situated within two clusters with mean ${ }^{125}$ I-NGF labeling indices of 2 and 8 and mean trk labeling indices of 1 and 10 , respectively. Upon curve fitting of trk frequency histograms to a double normal distribution with the Levenberg-Marquardt algorithm (Press et al., 1988), 60\% (54-67\%) were lightly labeled with mean index $1.5(1.1-2.2)$ and $40 \%$ were heavily labeled with mean index 25
(9.2-54). All three DRG contained some intermediately labeled neurons that could not confidently be classified into one or the other groups.

\section{Trigeminal, nodose, and sympathetic ganglia}

For both NGF-receptor radioautography and LNGFR hybridization, results for trigeminal ganglia were similar to those for L5 DRG (Figs. 3, 4). Again, those neurons with NGF labeling indices of $>3$ almost always had LNGFR labeling indices of $>3$ but a population of neurons with abundant LNGFR hybridization and little binding could be clearly detected (Fig. $5 E$ ). The tight colocalization of trk mRNA and NGF-binding sites that was documented for lumbar DRG also appeared to be valid for trigeminal neurons (Fig. 4), although these data were not rigorously quantified.

A marked discrepancy between NGF binding or trk hybrid- 


\section{LNGFR}
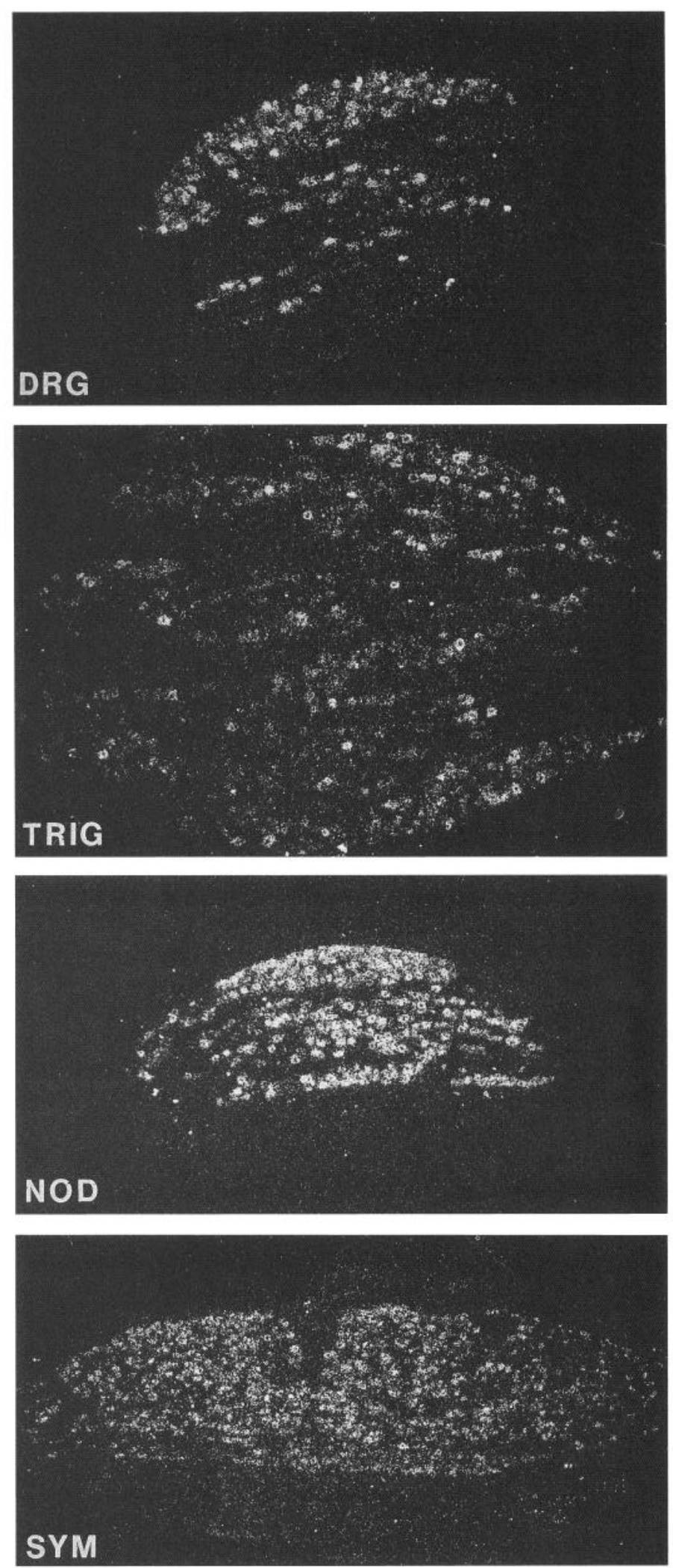

\section{TRK}
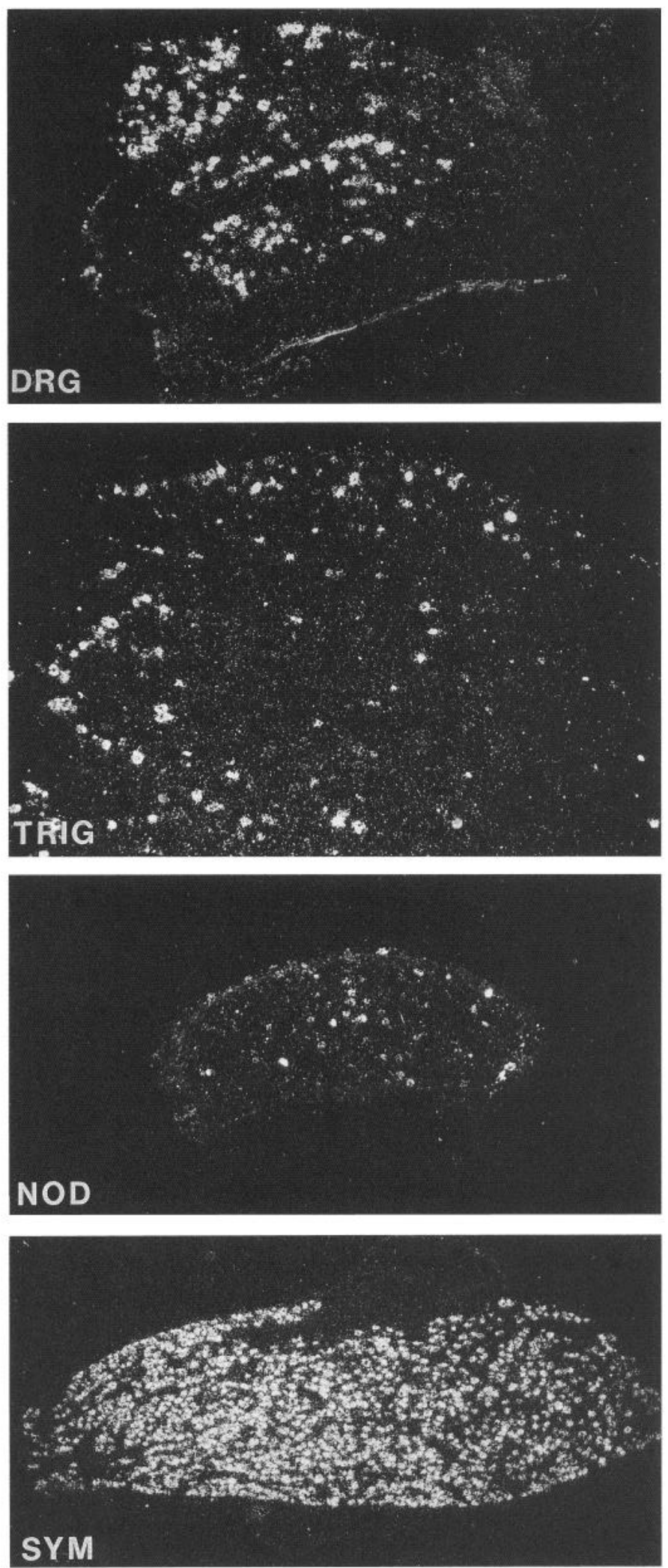

Figure 3. Dark-field photomicrographs of sections of lumbar DRG, trigeminal ganglia (TRIG), nodose ganglia (NOD), and sympathetic ganglia $(S Y M)$, all cut on the same chuck to show neuronal distributions and relative concentrations, are illustrated for LNGFR mRNA (left) or trk mRNA (right). For all three sensory ganglia, the expression of both LNGFR and trk is heterogeneous among neurons. In nodose ganglia, trk is strongly expressed in fewer neurons than in lumbar DRG or trigeminal ganglia and LNGFR is expressed at least as strongly in at least as many neurons. Virtually all sympathetic neurons are heavily labeled in both hybridizations. Magnification, $40 \times$. 
SYMPATHETIC
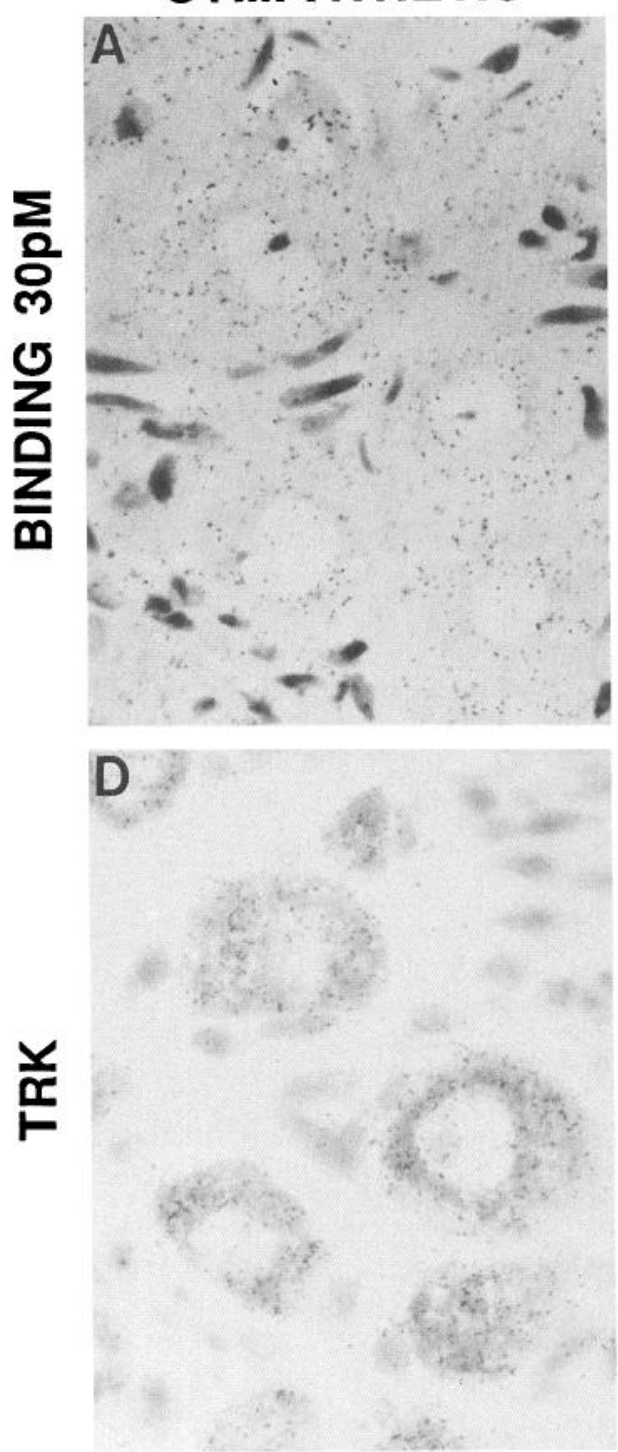

TRIGEMINAL
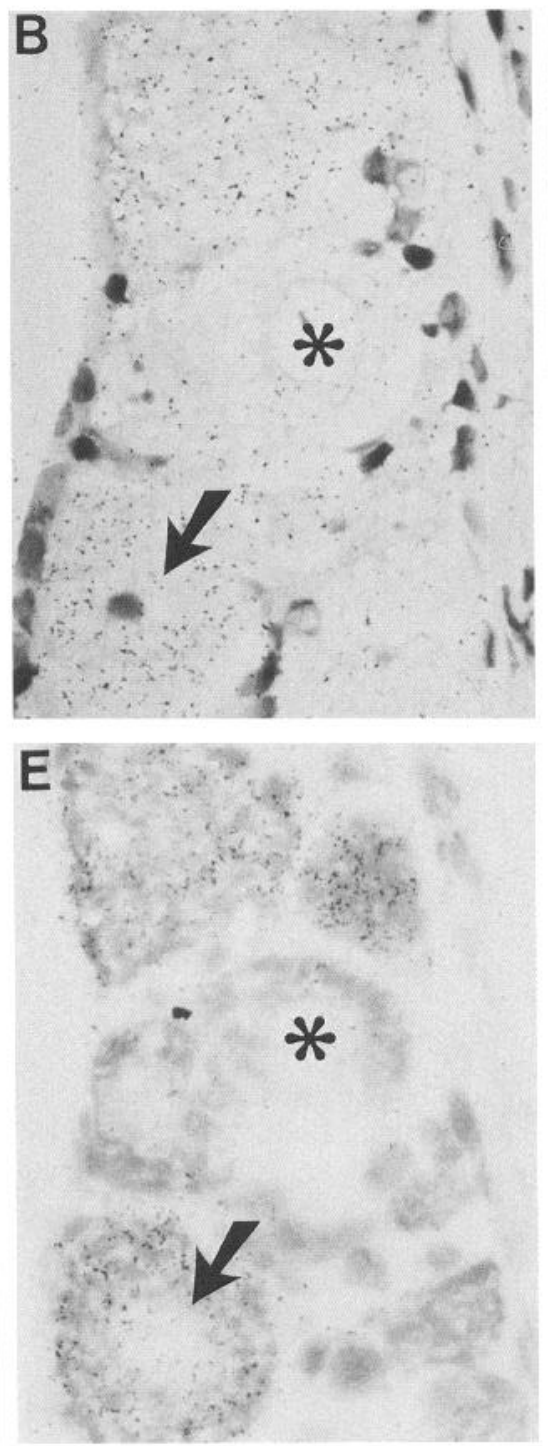

NODOSE
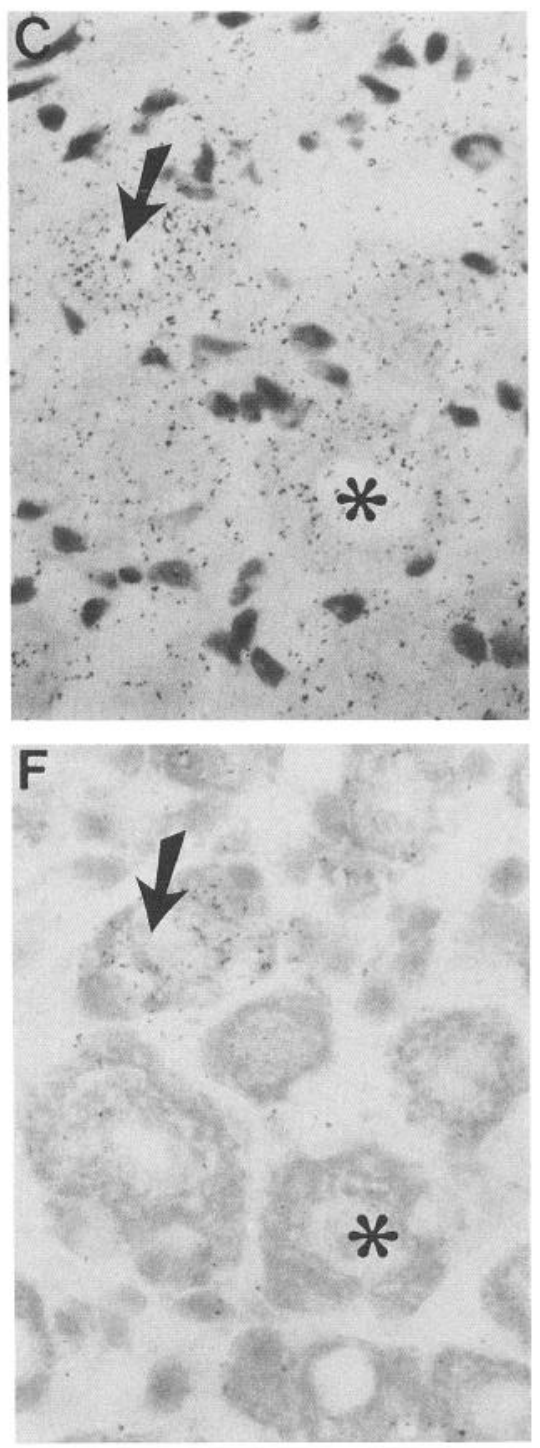

Figure 4. Photomicrographs of adjacent sections, $5 \mu \mathrm{m}$ thick, of sympathetic $(A, D)$, trigeminal $(B, E)$, and nodose $(C, F)$ neurons on a pair of slides, one processed for NGF receptor radioautography $(A-C)$ and the other for in situ trk hybridization $(D-F)$. Most or all sympathetic neurons have both high-affinity NGF-binding sites and strong expression of trk. Individual trigeminal neurons show comparable labeling with each procedure with either strong (arrows) or near-background labeling (asterisks). In the nodose ganglion, neurons with strong expression of trk are heavily labeled with ${ }^{125}$ I-NGF (arrows) but some neurons with little or no trk mRNA (asterisks) have more ${ }^{125}$ I-NGF labeling than corresponding cells in the trigeminal ganglion. Magnification, $700 \times$.

ization and LNGFR hybridization was apparent in nodose neurons (Fig. 3). The percentage of neurons with strong expression of trk was estimated to be $5 \%$ in nodose ganglia, considerably less than in DRG or trigeminal ganglia (Fig. 4). In contrast, the frequency histograms of the logarithms of LNGFR labeling indices in two nodose ganglia were rather similar to those for DRG and trigeminal ganglia, fitting single normal distributions (Fig. 5D). The mean density of LNGFR labeling appeared to be as high or higher in nodose ganglia than in DRG when sections from the two ganglia were processed on the same slide (Fig. 3). More than one-half of the neurons in nodose ganglia had abundant LNGFR mRNA but little or no trk mRNA (Fig. 3). In NGF receptor radioautography preparations of nodose ganglia (Fig. $5 B$ ), the percentage of neurons with dense labeling, presumably with high-affinity receptors, was difficult to define precisely because of overlap with a larger population of neurons with intermediate labeling.

Virtually all neurons in sympathetic ganglia displayed abundant NGF-binding sites, LNGFR mRNA, and trk mRNA (Figs. $3,4)$.

\section{Nerve injury and NGF infusion}

The changes of NGF binding sites in sensory neurons following axotomy and/or infusion of NGF (Figs. 6, 7) were consistent with those described in a previous publication (Verge et al., 1989a). Two to three weeks after sciatic nerve transection, the density of high-affinity NGF-binding sites on L5 DRG neurons was decreased and the normal bimodal pattern became unimodal with loss of the more heavily labeled population (Fig. $7 D$ ). NGF infusion partially reversed the effects of axotomy on 
TRIGEMINAL
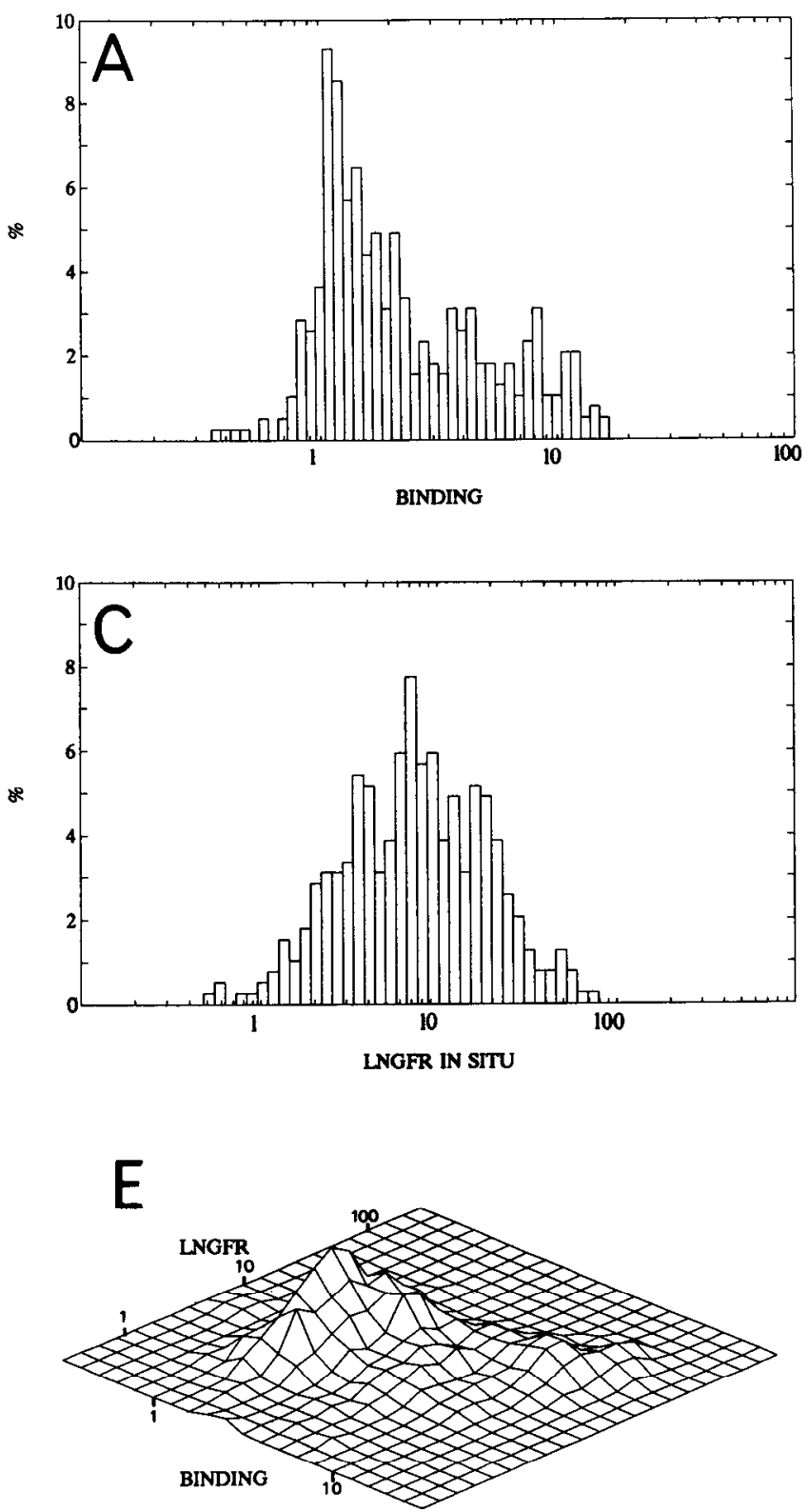

NODOSE
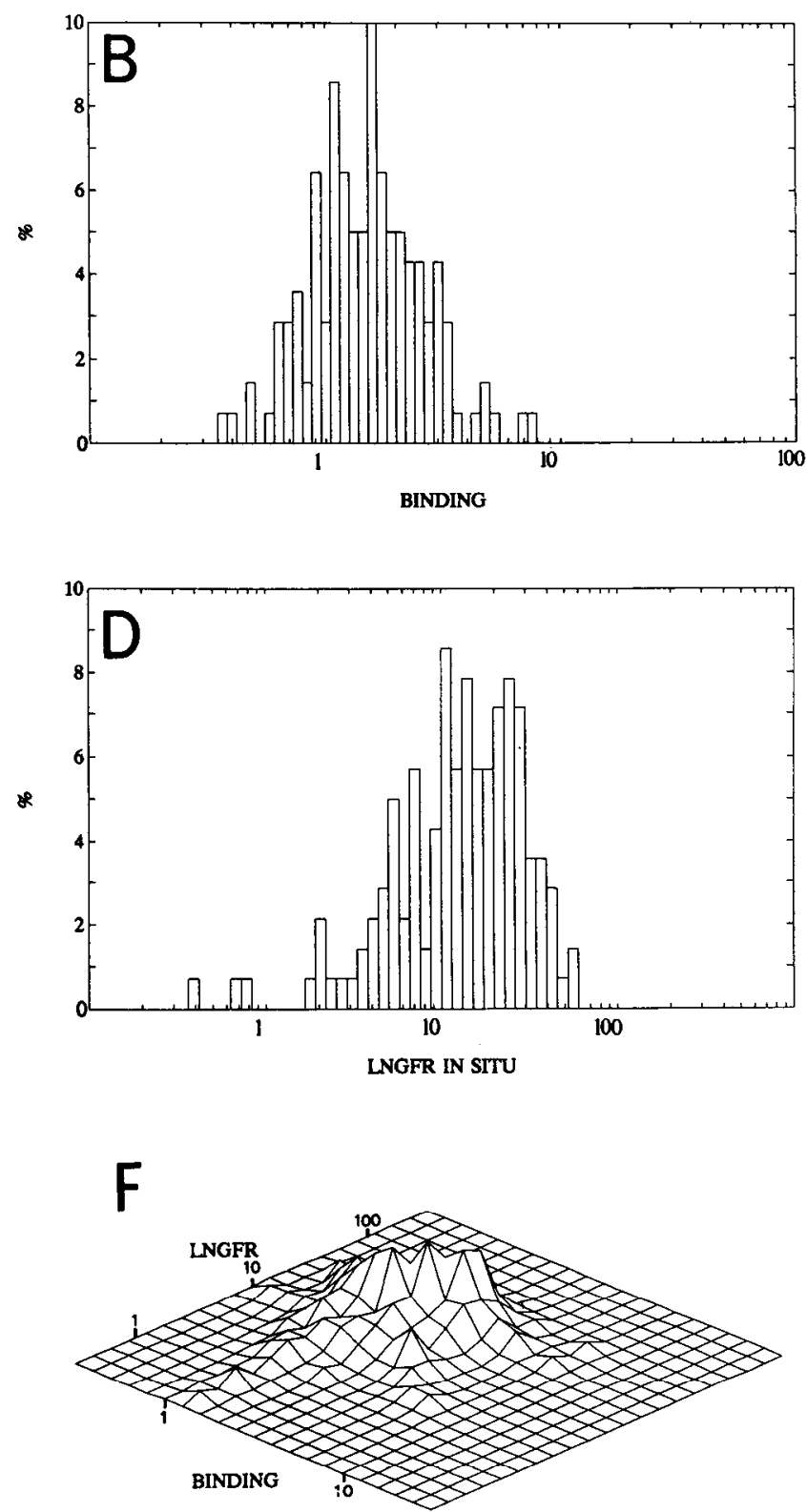

Figure 5. Frequency histograms of neuronal labeling by LNGFR hybridization $(C, D)$ and NGF receptor radioautography $(A, B)$ plus threedimensional histograms $(E, F)$ to show the relationship between the NGF binding sites and LNGFR mRNA in a trigeminal and nodose ganglion. In the trigeminal ganglion, the two markers are moderately well correlated although not all neurons with strong LNGFR labeling have high-affinity NGF receptors $(E)$. In the nodose ganglia, LNGFR labeling appears to be more prominent than in the trigeminal ganglion but neurons with highaffinity binding sites are scarce $(F)$.

binding sites (Fig. $7 K$ ) but did not appreciably influence NGF binding to neurons with intact axons (Fig. $7 H$ ). For the most heavily labeled one-third of neurons, which normally bear highaffinity receptors, the mean labeling index fell to $50 \%$ of normal after axotomy and returned to $76 \%$ with infusion of NGF. As calculated previously (Verge et al., 1989a), the changes in total numbers of receptors are considerably greater than suggested by these labeling indices.

Three to four weeks following sciatic nerve transection, labeling with the LNGFR probe was consistently diminished in all ipsilateral L5 DRG examined (Fig. 7D). This diminution was evident by $2 \mathrm{~d}$ and persisted at least 9 weeks after injury (data not shown). NGF infusion restored LNGFR labeling to slightly above normal values in axotomized neurons (Fig. $7 J$ ) and resulted in supranormal LNGFR labeling of otherwise normal DRG (Fig. $7 G$ ). Two series of LNGFR hybridizations were quantified with mean labeling indices of $54 \%, 200 \%$, and $112 \%$ of normal after nerve transection, NGF infusion without nerve transection, and nerve transection plus NGF infusion, respectively. The frequency histograms of the logarithms of LNGFR labeling indices became bimodal after NGF infusion (Fig. $7 G$ ). In colocalization analyses, NGF infusion was shown to increase LNGFR mRNA in the one-third of neurons most densely labeled with ${ }^{125}$ I-NGF but not in the least heavily labeled third (Fig. 8).

trk labeling of L5 DRG neurons was consistently reduced by 
LNGFR
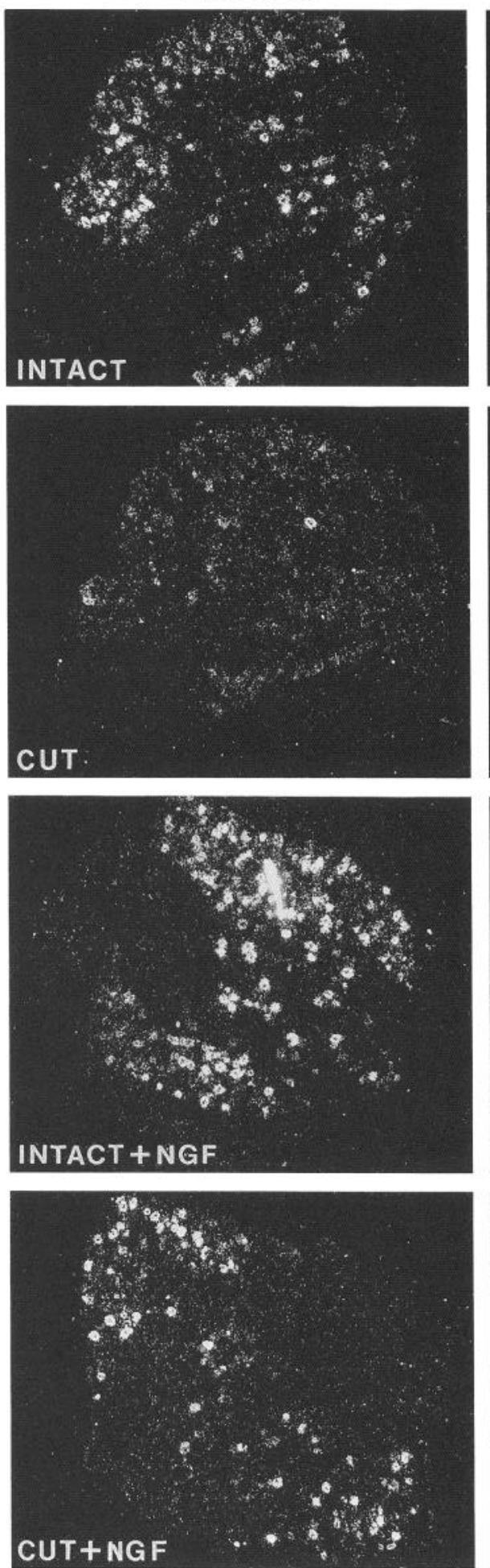

\section{BINDING}
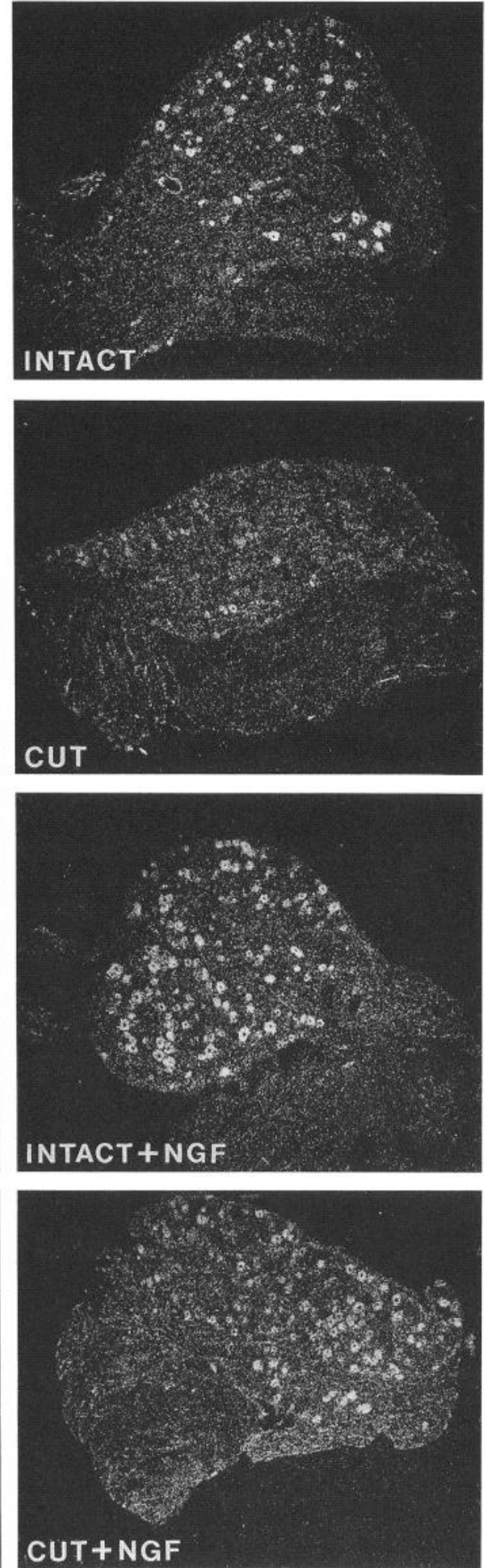

TRK
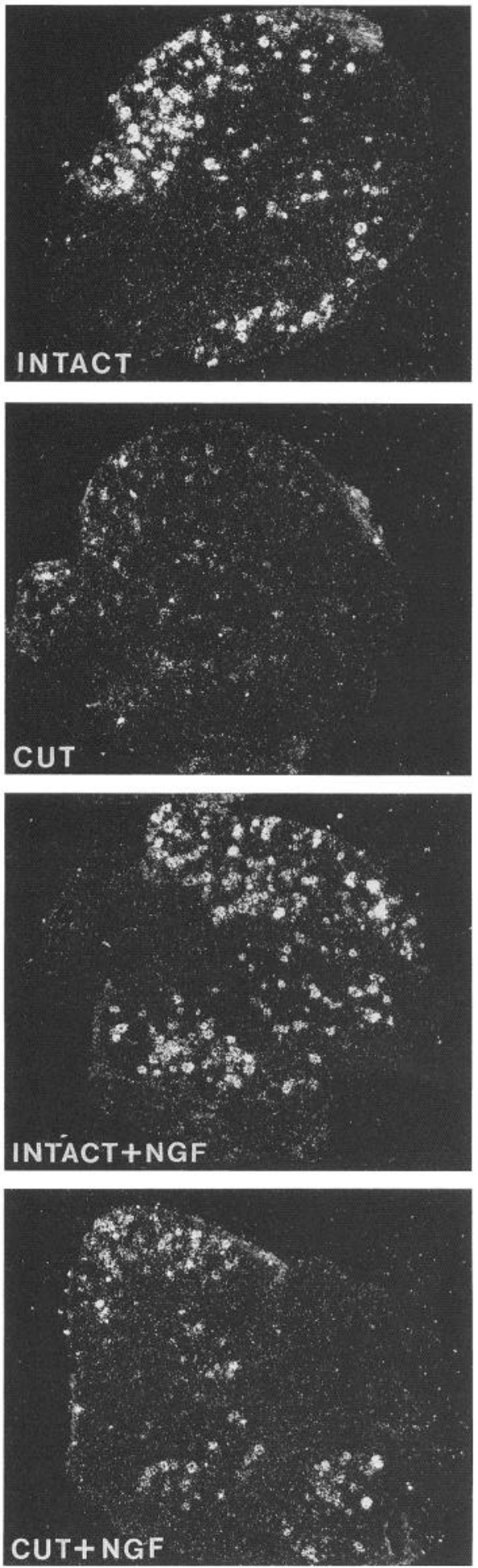

Figure 6. Dark-field photomicrographs to show sections of L5 DRG processed for LNGFR hybridization or trk hybridization and L4 DRG from the same animals processed for NGF receptor radioautography (BINDING). The DRG are associated with normal sciatic nerves or sciatic nerves cut 3 weeks previously and are exposed to intrathecally infused NGF or control solution infused from 14-21 d after axotomy. Nerve transection decreases the labeling in all three preparations and its effects are, to greater or lesser extent, counteracted by exogenous NGF. NGF infusion superinduces LNGFR mRNA in otherwise normal ganglia but has little or no effect on NGF binding sites or trk mRNA. Magnification, $35 \times$. 
LNGFR IN SITU
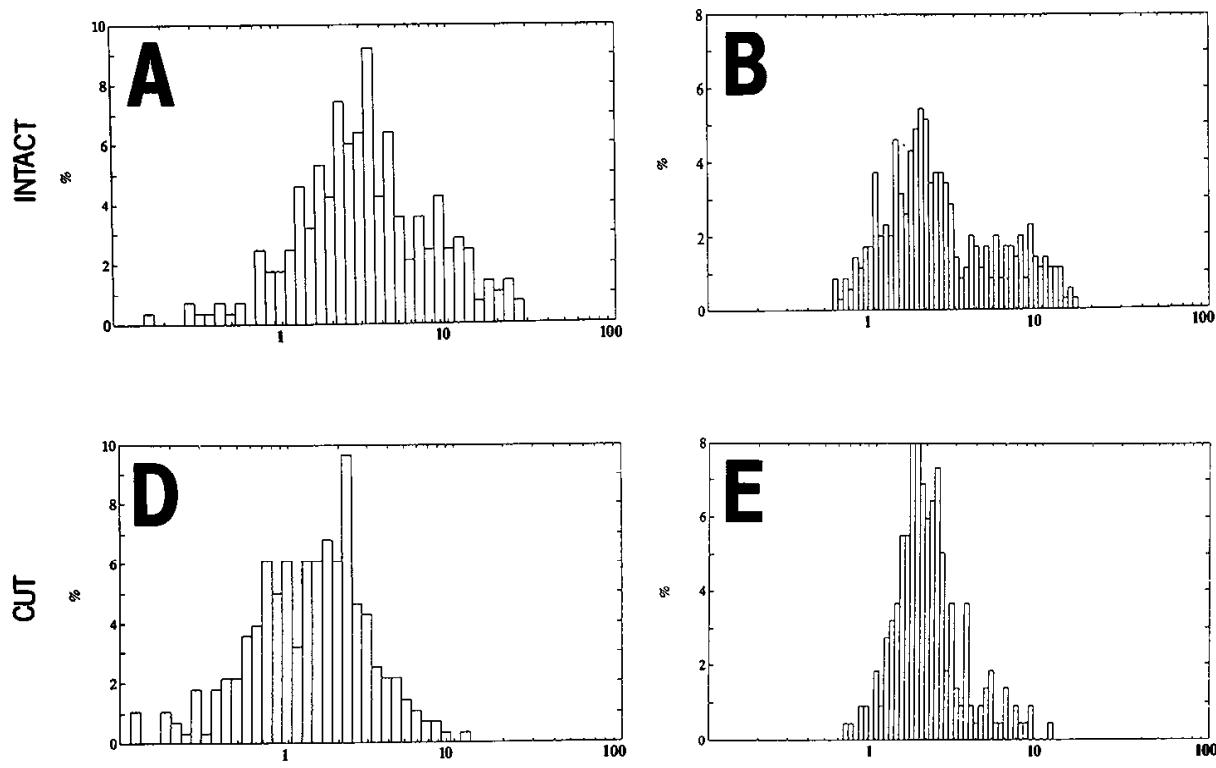

TRK IN SITU

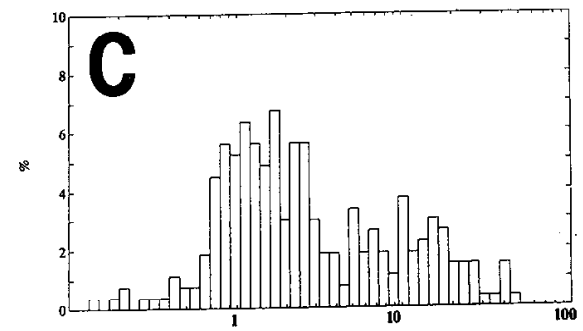

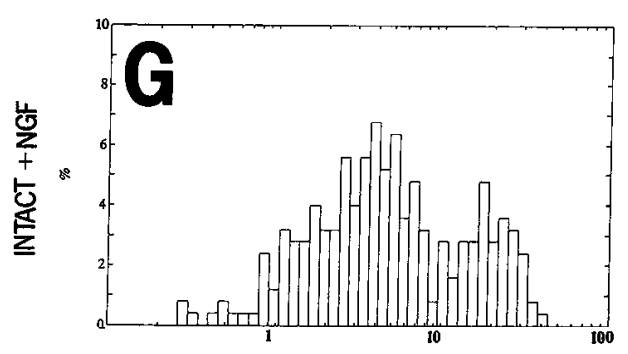
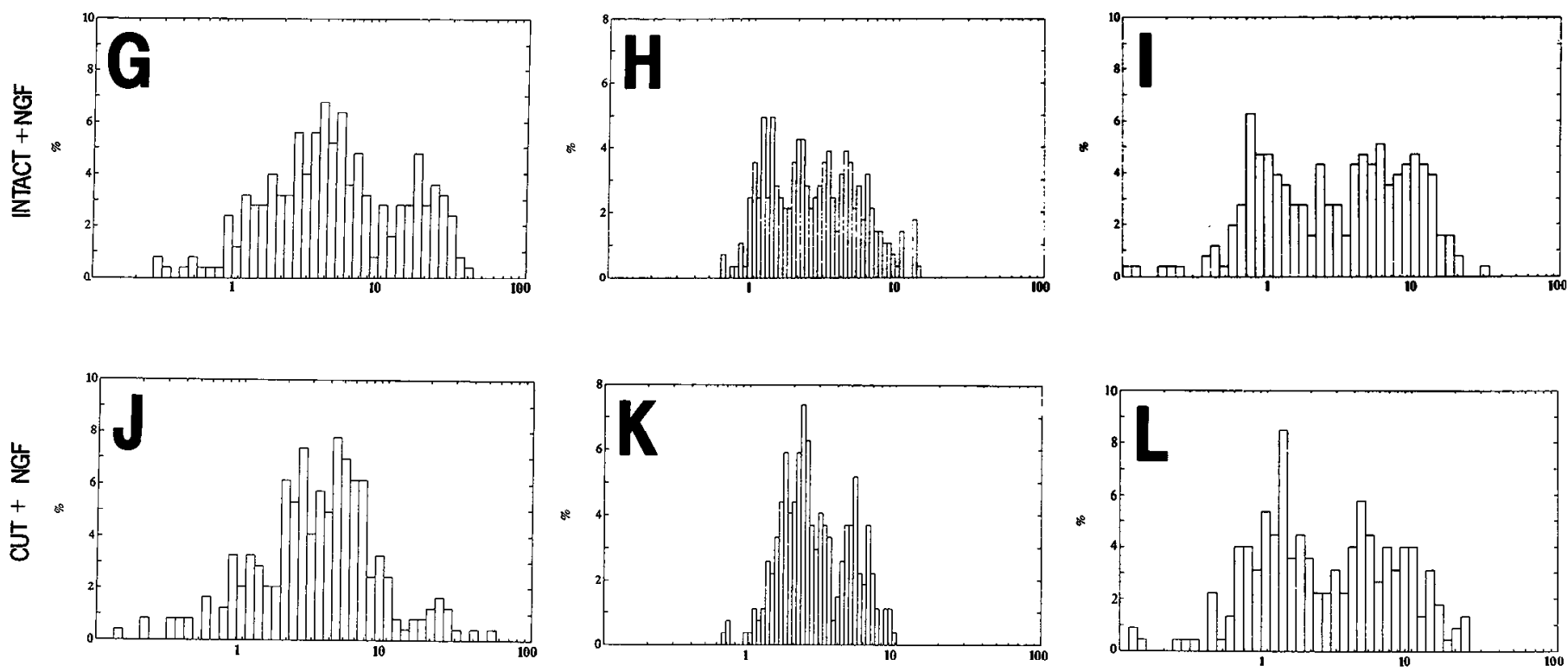

Figure 7. Quantification of the type of data illustrated in Figure 6. Frequency histograms of LNGFR, NGF (BINDING), and trk labeling indices are plotted for pairs of ganglia associated with nerve transection 3 weeks previously and/or NGF infusion from 14-21 d after axotomy. Data for LNGFR hybridization and NGF-receptor radioautography are from adjacent sections; trk hybridization is from another series of ganglia. The frequency histogram of LNGFR binding is unimodal for a normal ganglion $(A)$ and becomes bimodal after NGF infusion $(G)$. The frequency histograms of NGF receptor radioautography and trk hybridization arc bimodal for normal ganglia $(B, C)$ and become unimodal after nerve transection $(E, F)$.

nerve transection (Fig. $7 F$ ) and partially restored by NGF infusion (Fig. $7 L$ ). Administration of NGF did not increase trk labeling above normal values in uninjured neurons (Fig. 7I). In quantification of two series, trk labeling for the most heavily labeled one-third of neurons was $48 \%$ of normal after nerve transection and $61 \%$ of normal after transection plus NGF infusion. Frequency histograms of trk labeling resembled those of NGF labeling indices, with the bimodal patterns of normal ganglia becoming unimodal after nerve transection (Fig. $7 F$ ) and bimodal again after NGF infusion (Fig. $7 L$ ).

\section{Discussion}

The distribution of LNGFR mRNA among normal rat primary sensory neurons is more widespread than that of high-affinity NGF-binding sites. We speculate that those sensory neurons that have high concentrations of LNGFR mRNA but lack functional NGF receptors have receptors for other neurotrophins. Such neurons are particularly abundant in the nodose ganglion where both NT-3 and BDNF promote the survival of significant percentages of neurons (Davies et al., 1986; Ernfors et al., 1990; 
INTACT

A

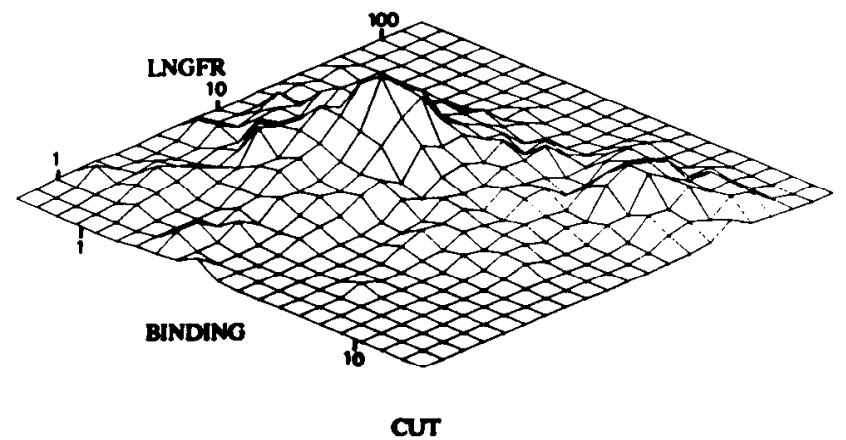

C

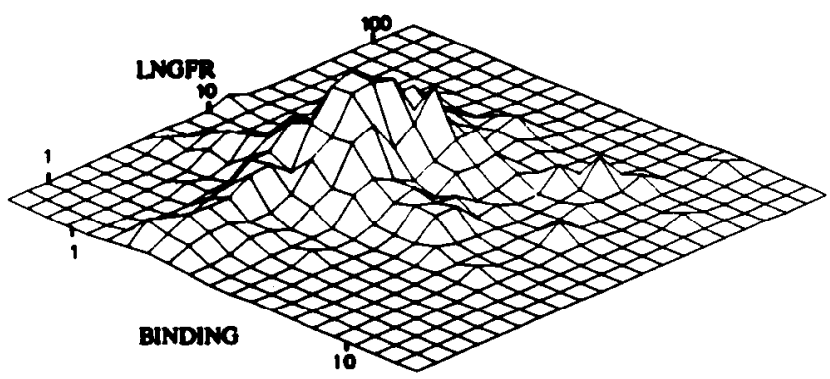

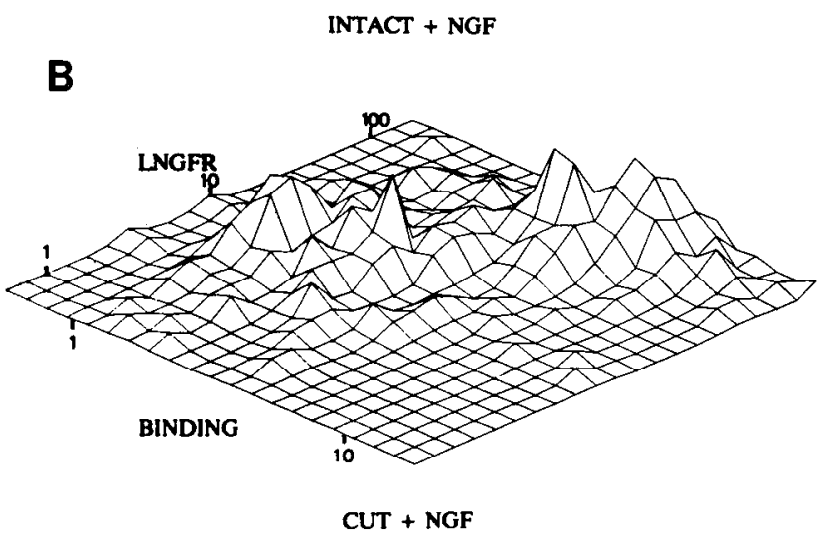

D

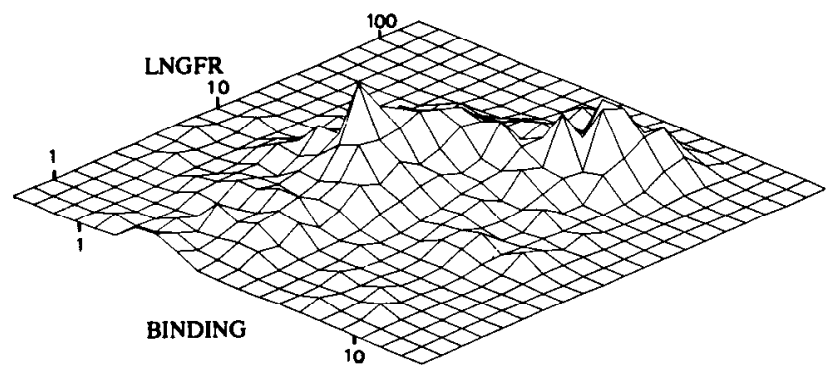

Figure 8. Two weeks after right sciatic nerve transection, rats were perfused intrathecally for 1 week with NGF or control solution. Threedimensional frequency histograms characterize labeling with the LNGFR probes and ${ }^{125}$ I-NGF. For neurons with high-affinity receptors (heavily labeled with ${ }^{125}$ I-NGF), NGF infusion induces LNGFR mRNA above normal concentrations in uninjured neurons $(B)$ and counteracts the downregulation of LNGFR mRNA in axotomized neurons (D). Neurons lacking high-affinity receptors (lightly labeled by ${ }^{125}$ I-NGF) are not appreciably influenced by NGF.

Hohn et al., 1990; Maisonpierre et al., 1990). Although the density of LNGFR mRNA labeling varies among sensory neurons, the single normal distribution in frequency histograms suggests that all mature sensory neurons have retained the capacity to express the LNGFR gene. The fact that all or almost all sensory neurons with high-affinity NGF receptors display relatively high concentrations of LNGFR mRNA could be explained by two hypotheses, not mutually exclusive. LNGFR could be present in NGF-responsive cells as an essential component of the functional NGF receptor and/or a result of induction by endogenous NGF.

The data on rat sympathetic and primary sensory neurons are consistent with tissue culture evidence on pheochromocytoma cells (Hempstead et al., 1991; Kaplan et al., 1991a,b; Klein et al., $1991 \mathrm{a}$; Loeb et al., 1991; Radeke and Feinstein, 1991) that trk is a necessary constituent of the functional NGF receptor.

In quantitative colocalization data in lumbar DRG (Fig. 2) and observations on trigeminal ganglia, it is concluded that neurons have high-affinity binding sites if and only if they have abundant trk mRNA. The underlying assumption that ${ }^{125}$ I-NGF labeling can be used to determine the presence or absence of high-affinity NGF receptors has been substantiated in previous studies of rat lumbar DRG (Verge et al., 1989a). In nodose ganglia, all neurons with high concentration of trk mRNA have many NGF-binding sites but some neurons moderately labeled with ${ }^{125}$ I-NGF have little or no trk mRNA. We suspect that neurons in this latter subpopulation have relatively abundant low-affinity binding without high-affinity binding as do Schwann cells in the distal segment of a transected nerve (Richardson et al., 1989). The less plausible explanation, that high-affinity NGF binding is present on some nodose neurons without trk, is technically difficult to exclude.

Infusion of NGF strongly upregulates LNGFR mRNA in both uninjured and injured primary sensory neurons. The effects of infused NGF on LNGFR mRNA are apparent only in the subpopulation of sensory neurons that have high-affinity NGF binding sites. Here, NGF may have an important function in regulating the synthesis of LNGFR as well as that of several neuropeptides (Goedert et al., 1981; Schwartz et al., 1982; Fitzgerald et al., 1985; Lindsay and Harmar, 1989; Verge et al., 1991), neurofilament (Verge et al., 1990b), and the growth-associated protein GAP-43 (Verge et al., 1990a). NGF has been shown previously to induce LNGFR mRNA and/or protein in basal forebrain cholinergic neurons (Cavicchioli et al., 1989; Hagg et al., 1989), sympathetic and sensory neurons (Lindsay et al., 1990; Miller et al., 1991), and pheochromocytoma cells (Bernd and Greene, 1984). In pheochromocytoma cells, this regulation is at the transcriptional level (Miller et al, 1991). Other agents that have been reported to influence expression of the LNGFR gene in diverse cell types are basic fibroblast growth factor (Birren and Anderson, 1990; Taiji et al., 1992) and ciliary neurotrophic factor (Hagg et al., 1992).

Exogenous NGF has no demonstrable effect on trk mRNA in uninjured sensory neurons but counteracts axotomy-induced downregulation of trk mRNA in the same neuronal population. The finding that NGF can influence expression of the trk gene, not predicted from tissue culture studies on PC12 pheochromocytoma cells (Kaplan et al., 1991a), could reflect either transcriptional or posttranscriptional regulation and could be direct or indirect. Only fragmentary information is now available con- 
cerning the actions of NGF, retinoic acid (Rodriguez-Tébar and Rohrer, 1991), and unidentified molecules in conferring the cellspecific capacity to express the trk gene or modulating its expression. One possible explanation for the different effects of NGF infusion on trk mRNA in uninjured and injured neurons is that availability of endogenous NGF is a limiting factor in expression of the trk gene after axotomy but not under normal circumstances. Alternatively, NGF may induce trk mRNA only in the presence of some additional factor that is activated in neurons by axonal injury.

trk mRNA and high-affinity NGF-binding sites appear to undergo parallel changes after axotomy and NGF infusion to the extent that measurements of an mRNA and protein can be compared. Although the changing concentrations of high-affinity receptors could entirely reflect changes in trk mRNA, the possibility cannot be excluded that the changes in LNGFR are contributory. Neither the normal data nor changes after axotomy or NGF infusion clearly discriminate whether or not LNGFR is necessary for functional high-aflinity NGF receptors.

\section{References}

Ausubel FM, Brent R, Kingston RE, Moore DD, Seidman JG, Smith KA, Struhl K (1987) Current protocols in molecular biology. New York: Wiley-Interscience.

Berkemeier LR, Winslow JW, Kaplan DR, Nikolics K, Goeddel DV, Rosenthal A (1991) Neurotrophin-5: a novel neurotrophic factor that activates trk and trkB. Neuron 7:857-866.

Bernd P, Greene LA (1984) Association of ${ }^{125}$ I-nerve growth factor with PC12 pheochromocytoma cells. J Biol Chem 259:15509-15516.

Birren SJ, Anderson DJ (1990) A v-myc-immortalized sympathoadrenal progenitor cell line in which neuronal differentiation is initiated by FGF but not NGF. Neuron 4:189-201.

Cavicchioli L, Flanigan TP, Vantini G, Fusco M, Polato P, Toffano G, Walsh FS, Leon A (1989) NGF amplifies expression of NGF receptor messenger RNA in forebrain cholinergic neurons of rats. Eur J Neurosci 1:258-262.

Cordon-Cardo C, Tapley P, Jing S, Nanduri V, O'Rourke E, Lamballe F, Kovary K, Klein R, Jones KR, Reichardt LF, Barbacid M (1991) The trk tyrosine protein kinase mediates the mitogenic properties of nerve growth factor and neurotrophin-3. Cell 66:173-183.

Dagerlind Å, Schalling M, Eneroth P, Goldstein M, Hökfelt T (1990) Effects of reserpine on phenylethanolamine $N$-methyltransferase mRNA levels in rat adrenal gland: role of steroids. Neurochem Int 17:343-356.

Davies AM, Thoenen H, Barde Y-A (1986) The response of chick sensory neurons to brain-derived neurotrophic factor. J Neurosci 6 : 1897-1904.

Ernfors P, Henschen A, Olson L, Persson H (1989) Expression of nerve growth factor receptor mRNA is developmentally regulated and increased after axotomy in rat spinal cord motoneurons. Neuron 2:1605-1613.

Ernfors P, Ibáñez CF, Ebendal T, Olson L, Persson H (1990) Molecular cloning and neurotrophic activities of a protein with structural similarities to nerve growth factor: developmental and topographical expression in the brain. Proc Natl Acad Sci USA 87:5454-5458.

Fitzgerald M, Wall PD, Goedert M, Emson PC (1985) Nerve growth factor counteracts the neurophysiological and neurochemical effects of chronic sciatic nerve section. Brain Res 332:131-141.

Goedert M, Stoeckel K, Otten U (1981) Biological importance of the retrograde axonal transport of nerve growth factor in sensory neurons. Proc Natl Acad Sci USA 78:5895-5898.

Hagg T, Fass-Holmes B, Vahlsing HL, Manthorpe M, Conner JM, Varon S (1989) Nerve growth factor (NGF) reverses axotomy-induced decreases in choline acetyltransferase, NGF receptor and size of medial septum cholinergic neurons. Brain Res 505:29-38.

Hagg T, Quon D, Higaki J, Varon S (1992) Ciliary neurotrophic factor prevents neuronal degeneration and promotes low affinity NGF receptor expression in the adult rat CNS. Neuron 8:145-158.

Hempstead BL, Martin-Zanca D, Kaplan DR, Parada LF, Chao MV (1991) High-affinity NGF binding requires coexpression of the trk proto-oncogene and the low-affinity NGF receptor. Nature 350:678683.

Hohn A, Leibrock J, Bailey K, Barde Y-A (1990) Identification and characterization of a novel member of the nerve growth factor/brainderived neurotrophic factor family. Nature 344:339-341.

Ibáñez CF, Ebendal T, Barbany G, Murray-Rust J, Blundell TL, Persson H (1992) Disruption of the low-affinity receptor binding site in nerve growth factor allows neuronal survival and differentiation through binding to the product of the proto-oncogene trk. Cell 69:329-341.

Johnson D, Lanahan A, Buck CR, Sehgal A, Morgan C, Mercer E, Bothwell M, Chao M (1986)Expression and structure of the human NGF receptor. Cell 47:545-554.

Kaplan DR, Martin-Zanca D, Parada LF (1991a) Tyrosine phosphorylation and tyrosine kinase activity of the trk proto-oncogene product induced by NGF. Nature 350:158-160.

Kaplan DR, Hempstead BL, Martin-Zanca D, Chao MV, Parada LF (1991b) The trk proto-oncogene product: a signal transducing receptor for nerve growth factor. Science 252:554-558.

Klein R, Jing S, Nanduri V, O'Rourke E, Barbacid M (1991a) The trk proto-oncogene encodes a receptor for nerve growth factor. Cell 65:189-197.

Klein R, Nanduri V, Jing S, Lamballe F, Tapley P, Bryant S, CordonCardo C, Jones KR, Reichardt LF, Barbacid M (1991b) The trkB tyrosine protein kinase is a receptor for brain-derived neurotrophic factor and neurotrophin-3. Cell 66:395-403.

Lamballe F, Klein R, Barbacid M (1991) trkC, a new member of the trk family of tyrosine protein kinases is a receptor for neurotrophin3. Cell 66:967-979.

Large TH, Weskamp G, Helder JC, Radeke MJ, Misko TP, Shooter EM, Reichardt LF (1989) Structure and developmental expression of the nerve growth factor receptor in the chicken central nervous system. Neuron 2:1123-1134.

Lindsay RM, Harmar AJ (1989) Nerve growth factor regulates expression of neuropeptide genes in adult sensory neurons. Nature 337: 362-364.

Lindsay RM, Shooter EM, Radeke MJ, Misko TP, Dechant G, Thoenen $\mathrm{H}$, Lindholm D (1990) Nerve growth factor regulates expression of the nerve growth factor receptor gene in adult sensory neurons. Eur J Neurosci 2:389-396.

Loeb DM, Maragos J, Martin-Zanca D, Chao MV, Parada LF, Greene LA (1991) The trk proto-oncogene rescues NGF responsiveness in mutant NGF-nonresponsive PC12 cell lines. Cell 66:961-966.

Longo FM, Woo JE, Mobley WC (1989) Purification of nerve growth factor. In: Nerve growth factors (Rush RA, ed), pp 3-30. Chichester: Wiley.

Maisonpierre PC, Belluscio L, Squinto S, Ip NY, Furth ME, Lindsay RM, Yancopoulos GD (1990) Neurotrophin-3: a neurotrophic factor related to NGF and BDNF. Scicnce 247:1446-1451.

Martin-Zanca D, Oskam R, Mitra G, Copeland T, Barbacid M (1989) Molecular and biochemical characterization of the human trk protooncogene. Mol Cell Biol 9:24-33.

Meakin SO, Suter V, Drinkwater CC, Welcher AA, Shooter EM (1992) The rat trk protooncogene product exhibits properties characteristic of the slow nerve growth factor receptor. Proc Natl Acad Sci 89:23742378.

Miller FD, Mathew TC, Toma JG (1991) Regulation of nerve growth factor receptor gene expression by nerve growth factor in the developing peripheral nervous system. J Cell Biol 112:303-312.

Press WH, Flannery BP, Teukolsky SA, Vetterling WT (1988) Numerical recipes in C. Cambridge: Cambridge UP.

Radeke MJ, Feinstein SC (1991) Analytical purification of the slow, high affinity NGF receptor: identification of a novcl $135 \mathrm{kd}$ polypeptide. Neuron 7:141-150.

Radeke MJ, Misko TP, Hsu C, Herzenberg LA, Shooter EM (1987) Gene transfer and molecular cloning of the rat nerve growth factor receptor. Nature 325:593-597.

Richardson PM, Riopelle RJ (1984) Uptake of nerve growth factor along peripheral and spinal axons of primary sensory neurons. J Neurosci 4:1683-1689.

Richardson PM, Verge VMK, Riopelle RJ (1989) Quantitative radioautography for NGF receptors. In: Nerve growth factors (Rush RA, ed), pp 315-326. Chichester: Wiley.

Rodriguez-Tébar A, Rohrer H (1991) Retinoic acid induces NGFdependent survival response and high-affinity NGF receptors in immature chick sympathetic neurons. Development 112:813-820. 
Rodriguez-Tébar A, Dechant G, Barde Y-A (1990) Binding of brainderived neurotrophic factor to the nerve growth factor receptor. Neuron 4:487-492.

Schneider R, Schweiger M (1991) A novel modular mosaic of cell adhesion motifs in the extracellular domains of the neurogenic trk and trk B tyrosine kinase receptors. Oncogene 6:1807-1811.

Schwartz JP, Pearson J, Johnson EM (1982) Effect of exposure to antiNGF on sensory neurons of adult rats and guinea pigs. Brain Res 244 : 378-381.

Soppet D, Escandon E, Maragos J, Middlemas DS, Reid SW, Blair J, Burton LE, Stanton BR, Kaplan DR, Hunter T, Nikolics K, Parada LF (1991) The neurotrophic factors brain-derived neurotrophic factor and neurotrophin-3 are ligands for the trkB tyrosine kinase receptor. Cell 65:895-903.

Squinto SP, Stitt TN, Aldrich TH, Davis S, Bianco SM, Radziejewski C, Glass DJ, Masiakowski P, Furth ME, Valenzuela DM, DiStefano PS, Yancopoulos GD (1991) trkB encodes a functional receptor for brain-derived neurotrophic factor and neurotrophin-3 but not nerve growth factor. Cell 65:885-893.

Sutter A, Riopelle RJ, Harris-Warrick RM, Shooter EM (1979) Nerve growth factor receptors. J Biol Chem 254:5972-5982.

Taiji M, Taiji K, Deyerle KL, Bothwell M (1992) Basic fibroblast growth factor enhances nerve growth factor receptor gene promoter activity in human neuroblastoma cell line CHP100. Mol Cell Biol 12:2193-2201.

Verge VMK, Riopelle RJ, Richardson PM (1989a) Nerve growth factor receptors on normal and injured sensory neurons. J Neurosci 9 : 914-922.

Verge VMK, Richardson PM, Benoit R, Riopelle RJ (1989b) Histochemical characterization of sensory neurons with high-affinity receptors for nerve growth factor. J Neurocytol 18:583-591.

Verge VMK, Tetzlaff W, Richardson PM, Bisby MA (1990a) Correlation between GAP43 and nerve growth factor receptors in rat sensory neurons. J Neurosci 10:926-934.

Verge VMK, TetzlaffW, Bisby MA, Richardson PM (1990b) Influence of nerve growth factor on neurofilament gene expression in mature primary sensory neurons. J Neurosci 10:2018-2025.

Verge VMK, Richardson PM, Wiesenfeld-Hallin Z, Hökfelt T (1991) Differential influence of nerve growth factor on neuropeptide expression in intact and injured adult sensory neurons. Eur J Neurosci Suppl $4: 288$.

Weskamp G, Reichardt LF (1991) Evidence that biological activity of NGF is mediated through a novel subclass of high affinity receptors. Neuron 6:649-663. 